\title{
NEWS MEDIA USE AND CIVIC ENGAGEMENT IN THE PERSPECTIVE OF UNIVERSITY STUDENTS: SOCIAL CAPITAL AND CIVIC ACCOUNTABILITY AS MEDIATING MECHANISM
}

\author{
Ibrar Ahmed \\ Research Scholar, \\ Faculty of Media and Communication Studies, University of Central Punjab \\ Lahore, Pakistan \\ Email: ibrargcs73@gmail.com

\section{Steven A. Beebe} \\ Professor Emeritus, \\ Department of Communication Studies, Texas State University, \\ Taxas, USA \\ Email: $\underline{\text { sb03@txstate.edu }}$

\section{Andleeb Ikhlaq} \\ Research Scholar, \\ Institute of Communication Studies, University of Punjab, \\ Lahore, Pakistan \\ Email: andleebchattha123@gmail.com
}

\begin{abstract}
This study explores the relationship between news media use and civic engagement. The investigation also examines the mediating role of social capital and civic accountability between news media use and civic attitude/behavior. Uses and gratification theory provides the theoretical framework for the study. Using a crosssectional survey design, this study collects data from 367 respondents. Findings using structural equation modeling reveal that news media has positive effects on civic behavior. News media has a significant relationship with social capital and civic accountability. Furthermore, civic accountability plays a positive mediating role between news media use and civic attitude/behavior. The relationship between news media use and civic behavior is also mediated by social capital. No relationship was found between news media and civic attitude. In terms of civic attitude, the results of the direct and indirect effects of social capital also remain statistically nonsignificant.
\end{abstract}




\section{KEYWORDS}

News media, civic engagement, social capital, civic accountability.

\section{INTRODUCTION}

Mass media is considered as the eyes and ears of a society that plays a central role in disseminating information regarding newsworthy events. In the present age, people use multiple platforms to receive up-to-date information about the latest happenings around the globe (Molyneux, 2017). Such information strengthens the social fabric. Media is an important agent of socialization that plays a vital role in enhancing civic engagement (Hao, Wen, \& George, 2014; Livingstone \& Markham, 2008). In this regard, newspaper reading and internet use provide new avenues for civic mobilization (McLeod, 2000; Shah, McLeod, \& Yoon, 2001).

In addition to news media, social capital also plays a fundamental role in enhancing civic engagement. Social capital increases coordination for mutual benefits (Putnam, 1995). Social capital includes both formal participation in social groups and informal socializing with peers. The entire socialization process revolves around interpersonal trust. Social capital also facilitates associative behavior and enhances the level of civic engagement (Kim, 2007). Social trust converts 'They' into 'We', creates an atmosphere of brotherhood, unites people, and engenders a prosperous society (Uslaner, 2018). Media enhances engagement in civic activities by promoting social capital.

Civic accountability, a relatively underexplored variable, focuses on a sense of responsibility concerning an individual's role in society. Media is a key mechanism to instigate the sense of accountability among social members which in return enhances engagement (Bonner, 2009). It is the civic accountability that motivates and encourages individuals to examine their behavior towards social change. An individual understands his social responsibilities and works for the welfare of the community. Civic accountability is indispensable for a strong civil society (Finkel, Sabatini, \& Bevis, 2000).

Civic engagement is a broader term, not limited to political participation, but also includes involvement in community affairs such as volunteer community activities. The current study explores the relationship between news media use and civic engagement. This study also investigates the mediating effects of social capital and civic accountability. Although there is some understanding of the role of civic accountability on society, this study seeks to bridge this gap by exploring the effects of news media on civic accountability. 


\section{LITERATURE REVIEW}

\section{News Media Use and Civic Engagement}

Several research studies provide some understanding of relationships between news media use and civic engagement. Mahmood and Saud (2019) explored the relationship between Facebook use and civic engagement among a sample of 1245 respondents. The results indicated a significant relationship between Facebook use and the civic activities of youth. Likewise, Molyneux (2017) argued that multiplatform news consumption plays a positive role in leading people towards civic engagement. Contrary to previous studies, Zubair and Halim (2017) found no relationship between the new media use and the civic contribution of youth. They examined the effects of social networking sites among 195 respondents. Their study contradicts the findings of previous studies indicating no significant association between new media and engagement.

Mushtaq and Baig (2015) explored the relationship between television news consumption and civic participation among a sample of 246 respondents. The results showed that news consumption through television had a significant relationship with the civic contribution of youth. The study of Martens and Hobbs (2015) examined the relationship between media literacy and engagement. Findings inferred from the analysis of 400 respondents revealed that the latest information technology, knowledge, attitude, and media literacy enhanced participation in civic affairs. Likewise, Cheng, Liang, and Leung (2015) examined the influence of social networking use on civic engagement within the framework of uses and gratification. Results revealed that technological fulfillment desire, interpersonal communication, and social network use have a positive association with civic engagement.

Hao, Wen, and George (2014), when exploring the association between news consumption and civic contribution, obtained online data from 397 university students. Their results revealed that news consumption through new media had a positive influence on civic engagement. Additionally, Gil de Zuniga, Jung, and Valenzuela (2012) found a positive relationship between social media use for news and civic engagement. The results also showed a positive association between new media and social capital. Campbell and Kwak (2010) examined the association between smartphone use and civic engagement under the framework of uses and gratification. The analysis of 777 respondents showed that the adoption of the latest technology had significant effects on civic engagement. Individuals who use smartphones for exchanging information were more civically engaged. Kim (2007) examined the impacts of media exposure and social capital on civic engagement among 527 respondents. The results showed a positive connection between media use and engagement. It was also observed that the use of new media plays an effective role in enhancing civic engagement. 


\section{Direct and Indirect Effects of Social Capital}

Several studies have examined both the direct and indirect effects of social capital on civic engagement. Jalalani and Shah (2019) examined the relationship between social capital and civic engagement by collecting data from university students. The results illustrated that bonding social capital and trust had a direct influence on civic actions. Rafique, Khoo, and Idrees (2016) conducted a study to check the level of civic engagement among 381 respondents. The results showed that civic responsibility and sensitivity had a positive association with engagement. This study resulted that the contribution of youth in civic activities had great potential for social capital.

Warren, Sulaiman, and Jaafar (2014) found that new media was significantly related to mutual trust which in result enhanced trust in state institutions. Moreover, mutual incentives encouraged citizens to participate in online civic activities by developing their interests. Similarly, Liu et al. (2014) identified a positive and direct relationship between a high level of social capital and civic behavior. Moreover, this study also observed partial mediating effects of social capital. Bonner (2009) found that media play a vital role in promoting social accountability while providing platforms for public discussion and mutual action for the betterment of society. This study observed the influence of media in creating social accountability concerning police violence through newspaper coverage. Son and Lin (2008) claimed that organizational networks play a central role in enhancing contribution to civic affairs.

The empirical literature suggests that media use for entertainment has negative impacts on social capital. Shah, Kwak, and Holbert (2001) found a negative relationship between internet use for entertainment and social capital. Likewise, Cho, Rojas, and Shah (2003) termed the internet as one of the major factors for having adverse civic consequences. Putnam (1995) claimed that television is responsible for the decline of social capital in the USA. In his opinion, television viewing has negative effects on social trust and engagement. Interestingly, he argued that print media especially newspapers have positive effects on social capital. Uslaner (1998) rejected Putnam's claim that television decline social trust and engagement. Putnam (2000) argued that those individuals who have a large social network are more likely to contribute to civic activities. Social trust removes barriers and opens new avenues for civic engagement. In addition, previous scholarly studies have also identified social capital as a potential mediating variable between news media and civic engagement (Collins, Neal, \& Neal, 2014; Zhong, 2014). To summarize, a critical review of previous studies identified a significant relationship between news media use and civic engagement (Campbell \& Kwak, 2010; Cheng, Liang, \& Leung, 2015; Hao et al., 2014; Kim, 2007; Molyneux, 2017; Mushtaq \& Baig, 2015). It is evident from previous scholarly studies that a significant relationship exists between news media and social capital, and social capital and civic engagement (Jalalani \& Shah, 2019; Liu et al., 2014; Putnam, 2000; Warren, 
Sulaiman, \& Jaafar, 2014). Nevertheless, a little is known about the direct and indirect effects of civic accountability. This particular study seeks to bridge this research gap.

\section{Theoretical Framework}

This study is grounded in the uses and gratification theory (UGT) as proposed by Katz, Blumler, and Gurevitch in 1974. This theory sheds light on the social and psychological origins of needs that cause expectations of media use (Katz \& Blumler, 1974). In essence, this theory predicts that people use different mediums to gratify their needs. Media users are active and media use is goal-oriented (Baran \& Davis, 2011). Describing the types of different needs, Leung (2009) argued that social media users generate online content to fulfill their recognition, cognitive, social, and entertainment needs. Uses and gratification approach has been extensively adopted to observe different kinds of media adoption (Campbell \& Kwak, 2010; Cheng, Liang, \& Leung, 2014; Leung \& Wei, 2000; Papacharissi \& Rubin, 2000). UGT theory is relevant to the current research study given that media users are active individual agents who consume news via different information mediums to gratify their needs. Above all, news media use may be a result of needs that are gratified and reflected in affective responses to civic attitude/behavior.

In addition to the UGT approach, this study can also be framed in the agenda-setting theory. This theory postulates that the media doesn't tell us what to think but influences what to think about (McCombs \& Shaw, 1993). An individual not only selects media to meet his needs but it further influences what we discuss and may have an influence on civic engagement. Several studies suggested that second-level agenda-setting has powerful effects on the relationship between media and civic engagement (Bryant \& Oliver, 2009; Kiousis \& McDevitt, 2008; Moon, 2013).

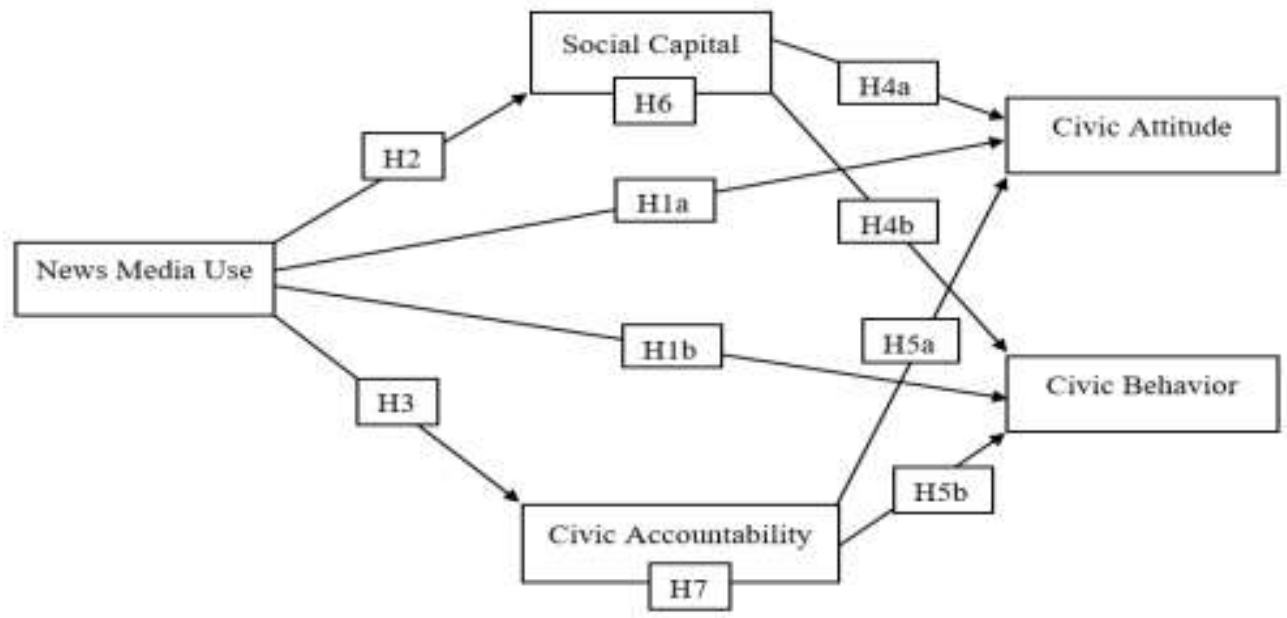

Figure 1. Proposed Hypothetical Model 
As shown in Figure 1, news media use is an independent variable that is anticipated to have a direct relationship with civic attitude/behavior. Civic attitude and behavior are dependent variables. Whereas social capital and civic accountability are mediating variables that link news media use and civic attitude/behavior.

\section{RESEARCH OBJECTIVES}

1. Explore the relationship between news media use and civic attitude/behavior.

2. Check the relationship between news media and social capital.

3. Examine the influence of news media use on civic accountability.

4. Identify the direct impacts of social capital and civic accountability on civic attitude/behavior.

5. Investigate the mediating role of social capital and civic accountability between the relationship of news media and civic attitude/behavior.

\section{RESEARCH HYPOTHESES}

1.1. News media use has a significant relationship with civic attitude.

1.1.2. News media use has a significant relationship with civic behavior.

1.2. News media use has a significant relationship with social capital.

1.3. News media use has a significant relationship with civic accountability.

1.4.1. Social capital has a significant relationship with civic attitude.

1.4.2. Social capital has a significant relationship with civic behavior.

1.5.1. Civic accountability is positively associated with civic attitude.

1.5.2. Civic accountability is positively associated with civic behavior.

1.6. Social capital mediates the relationship between news media and civic attitude/ behavior.

1.7. Civic accountability mediates the relationship between news media and civic attitude/behavior.

\section{RESEARCH METHODOLOGY \\ Participants and Sampling}

This study is based on quantitative methodology, also known as empiricist methodology. To carry out this study, a cross-sectional design vis-à-vis survey method was adopted. The population of this study was university students of Lahore. Participants were 367 young adults selected from various public and private higher education institutes of Lahore with the help of convenience sampling technique. The survey URL was shared with 800 students aged 18 to 33 via Email. At the end, 367 complete responses were received.

\section{Measurement}

\section{News media use}

Adopting a scale from Gil de Zuniga, Jung, and Valenzuela (2012), this study 
assessed news media use. Participants were asked to report how much they had read, seen, or listened to different news mediums to get information about events, public issues, and politics $(1=$ Never $; 5=$ Very often $)$. Seven news mediums were mentioned in response: newspaper, magazine, radio, television, social networking sites, online newspaper, and internet. Cronbach's Alpha for the measure was $(\alpha=.67, M=22.71$, $S D=4.20)$.

\section{Social Capital}

Social capital scale was adopted from the study of Kim (2007). It included six items such as "I participate in alumni activities" and "Most people can be trusted" ( $\alpha=.72$, $M=18.62, S D=3.78$ ).

\section{Civic Accountability}

Adapting the civic accountability scale developed by Flanagan, Syvertsen, and Stout (2007), this study measured civic accountability on a five-point Likert scale (1= Strongly disagree, 5 = Strongly agree). It included four items like "If I love Pakistan, I should notice its problems and work to correct them" ( $\alpha=.76, M=16.65, S D=2.62)$.

\section{Civic Engagement}

Adopting civic engagement scale developed by Doolittle and Faul (2013), this study measured civic engagement on a five-point Likert scale. This scale consists of two subscales: civic attitude and civic behavior. Civic attitude refers to the personal beliefs concerning involvement in civic affairs. It included eight items such as "I feel responsible for my community" ( $\alpha=.90, M=32.68, S D=4.77)$. Civic behaviors are actions that an individual takes to make a difference in his community. Civic behavior subscale included six items such as "I am involved in structured volunteer position in the community" ( $\alpha=.86, M=20.61, S D=4.68)$.

\section{Control Variables}

In this study, sociodemographic variables such as gender $(M=1.46, S D=0.49$ and female $46.6 \%)$, locale $(M=1.73, S D=0.44)$, age $(M=2.04, S D=0.89)$, and qualification $(M=2.81, S D=1.02)$ were included as control variables.

\section{DATA ANALYSIS}

To empirically test hypotheses, this study applied the Partial Least Square based Structural Equation Modeling (PLS-SEM) approach. Through this approach, we can easily handle the reflective measurement model and it works very well with a smaller sample size (Hair, Risher, Sarstedt, \& Ringle, 2019). This analysis technique is helpful especially when a research study is not properly in line with a particular theory or research objectives are not confirming a strong theory (Hair, Hult, Ringle, \& Sarstedt, 2017). First of all, researchers assessed the measurement model in which convergent 
and discriminant validity was examined. Then, the structural model was evaluated after controlling demographic variables. PLS bootstrapping (number of bootstrap samples is 5000) was applied to test mediating hypotheses.

\section{RESULTS}

As mentioned above, this study adopted a two-stage approach using PLS-SEM and evaluated both measurement and structural models. Measurement model as shown in Figure 2 depict beta values in the inner model, loading of items of different constructs in the outer model and $\mathrm{R}$ square vales in constructs. Structural model presented in Figure 3 shows beta and probability vales in inner model. The relationship is significant at .05 level. Table 1 presents the results of factors loadings, composite reliability, average variance extracted (AVE), and $\left(\mathrm{R}^{2}\right)$. .70 value for loadings, .70 for composite reliability, and a minimum .50 value for AVE is recommended (Hair et al., 2017). Keeping in view this criterion, the composite reliability of all construct was up to the required standard ranging from 0.77 to 0.92 . In addition to news media use and social capital, all constructs have up to the mark loadings and AVE scores. Keeping in view the criteria of Chin (1998), findings of $\mathrm{R}^{2}$ as shown in Table 1 indicate that civic attitude and civic behavior have moderate values. While social capital and civic accountability have weak values.

Table 1: Assessment of Convergent Validity

\begin{tabular}{lllll}
\hline Constructs & Loadings & CR & AVE & $\mathrm{R}^{2}$ \\
\hline & .617 & & & \\
& .583 & & & \\
News media use & .256 & & & \\
& .656 & .77 & .33 & - \\
& .657 & & & \\
& .521 & & & \\
& .676 & & & \\
\hline \multirow{5}{*}{ Social capital } & .527 & & & \\
& .606 & .80 & .41 & \\
& .595 & & & \\
& .696 & & & \\
\hline & .717 & & & \\
\hline
\end{tabular}




\begin{tabular}{|c|c|c|c|c|}
\hline & .806 & & & \\
\hline \multirow{8}{*}{ Civic attitude } & .754 & \multirow{8}{*}{.92} & \multirow{8}{*}{.59} & \multirow{8}{*}{.49} \\
\hline & .757 & & & \\
\hline & .751 & & & \\
\hline & .825 & & & \\
\hline & .785 & & & \\
\hline & .847 & & & \\
\hline & .763 & & & \\
\hline & .643 & & & \\
\hline \multirow{6}{*}{ Civic behavior } & .669 & \multirow{6}{*}{.89} & \multirow{6}{*}{.59} & \multirow{6}{*}{.34} \\
\hline & .824 & & & \\
\hline & .827 & & & \\
\hline & .769 & & & \\
\hline & .799 & & & \\
\hline & .719 & & & \\
\hline
\end{tabular}

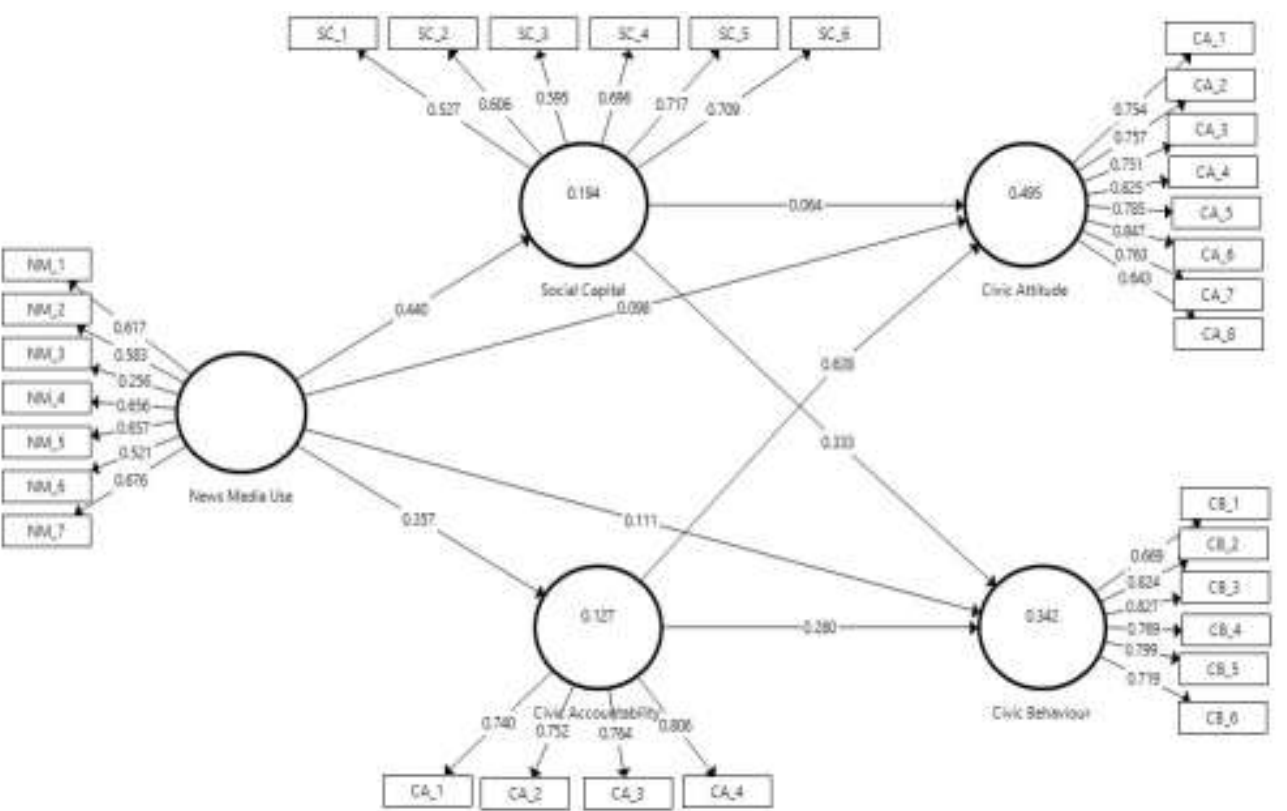

\section{Figure 2. Measurement Model}

The discriminant validity was measured using the criteria of Fornell and Larcker (1981). As shown in Table 2, diagonals (bold figures) are the square roots of the AVE. 
The rest of the values represent the correlation among latent variables. All diagonals have higher values as compared to nondiagonal which shows the discriminant validity criterion was satisfied.

Table 2: Discriminant Validity

\begin{tabular}{lccccc}
\hline Latent Variable & 1 & 2 & 3 & 4 & 5 \\
\hline 1. Civic Accountability & $\mathbf{. 7 6 6}$ & & & & \\
2. Civic Attitude & .693 & $\mathbf{. 7 6 8}$ & & & \\
3. Civic Behavior & .472 & .531 & $\mathbf{. 7 7}$ & & \\
4. News Media Use & .357 & .35 & .358 & $\mathbf{. 5 8 3}$ & \\
& & & & & \\
5. Social Capital & .458 & .395 & .511 & .44 & $\mathbf{. 6 4 5}$ \\
\hline
\end{tabular}

Hypotheses testing summarized in Table 3 indicated no relationship between news media use and civic attitude $(\beta=0.098, t=1.68, p=.09)$. H1a was not supported. And conversely, $\mathrm{H} 1 \mathrm{~b}$ which predicted a positive relationship between news media use and civic behavior was supported $(\beta=0.111, t=2.09, p=.03)$. In light of these results, it can be said that news media have direct and positive effects on civic behavior but not on civic attitude. In $\mathrm{H} 2$, news media use was predicted to have positive effects on social capital and the results demonstrated that the hypothesis was supported $(\beta=0.440, t=$ 9.96, $p<.001)$. Hypothesis 3 which predicted a significant positive effect of news media use on civic accountability was supported $(\beta=0.357, t=6.05, p<.001)$. The findings clearly showed that news media has a significant relationship with social capital and civic accountability.

Table 3: Results of the Hypotheses Testing

\begin{tabular}{lcccc}
\hline \multicolumn{1}{c}{ Hypothesis Path } & $\beta$ & $S D$ & t-value & p-value \\
\hline News Media Use -> Civic Attitude & 0.098 & 0.058 & 1.68 & .092 \\
News Media Use -> Civic Behavior & 0.111 & 0.053 & 2.09 & .036 \\
News Media -> Social Capital & 0.440 & 0.044 & 9.96 & .000 \\
News Media -> Civic Accountability & 0.357 & 0.059 & 6.05 & .000 \\
Social Capital -> Civic Attitude & 0.064 & 0.046 & 1.38 & .166 \\
Social Capital -> Civic Behavior & 0.333 & 0.055 & 6.06 & .000 \\
Civic Accountability -> Civic Attitude & 0.628 & 0.047 & 13.30 & .000 \\
Civic Accountability -> Civic & & & & \\
Behavior & 0.280 & 0.062 & 4.55 & .000 \\
News Media Use -> Social Capital -> & & & & \\
Civic Attitude & 0.028 & 0.021 & 1.36 & .173 \\
News Media Use -> Social Capital -> & & & & \\
Civic Behavior & 0.147 & 0.029 & 5.13 & .000 \\
\hline
\end{tabular}


News Media Use -> Civic

$\begin{array}{lllll}\text { Accountability } \rightarrow \text { Civic Attitude } & 0.224 & 0.043 & 5.20 & .000\end{array}$

News Media Use -> Civic

Accountability $\rightarrow$ Civic Behavior

$0.224-0.043-5.20$

.00

Furthermore, no relationship was found between social capital and civic attitude $(\beta=$ $0.064, t=1.38, p=.166)$. H4a was not supported. However, there was a positive association between social capital and civic behavior $(\beta=0.333, t=6.06, p<.001)$. $\mathrm{H} 4 \mathrm{~b}$ was supported. The results further illustrated that the relationship between civic accountability and civic attitude was significant $(\beta=0.628, t=13.30, p<.001)$. H5a was supported. As predicted by $\mathrm{H} 5 \mathrm{~b}$, civic accountability had a significant and positive association with civic behavior $(\beta=0.280, t=4.55, p<.001)$.

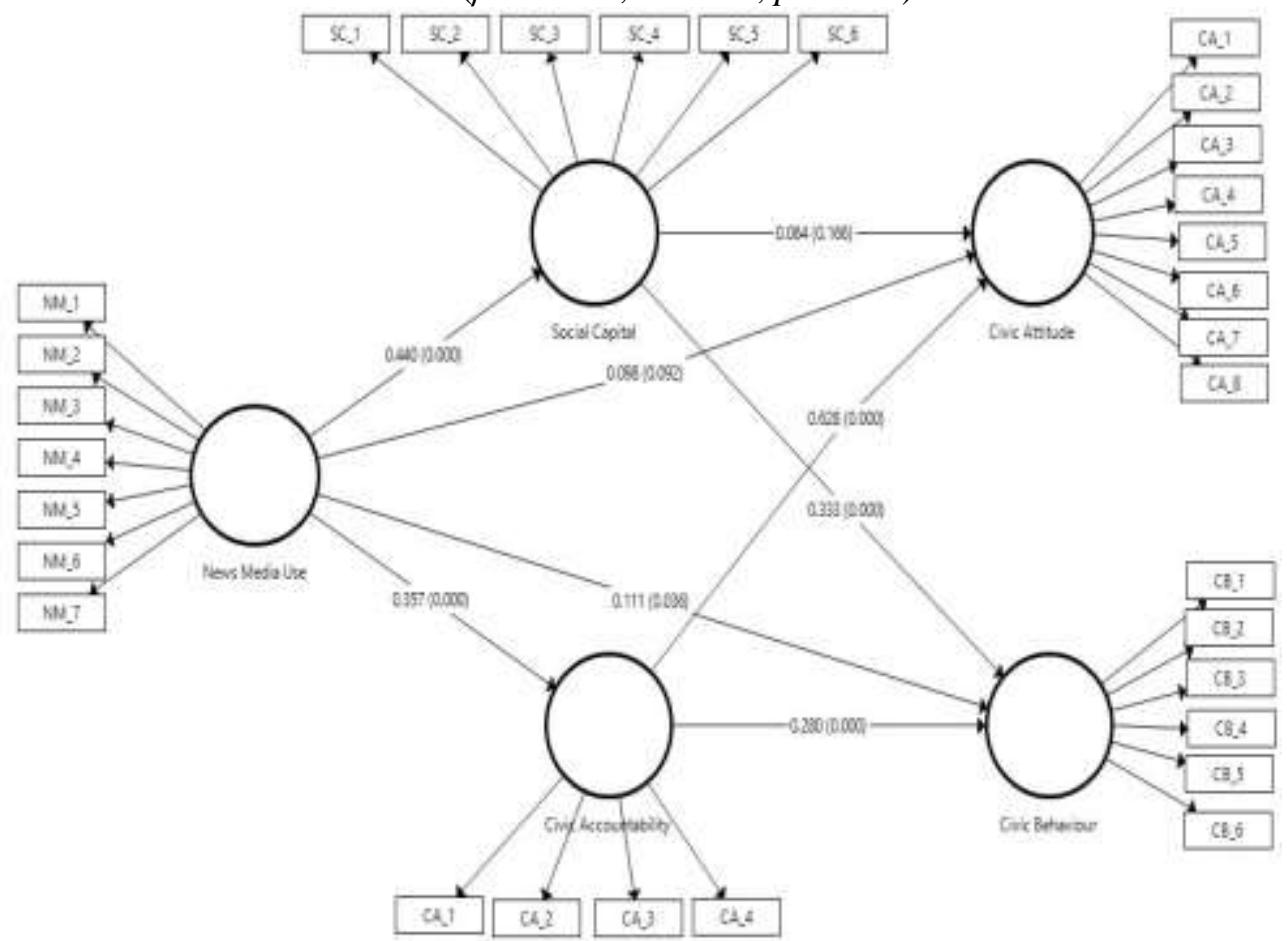

Figure 3. Structural Model

As hypothesized in H6, social capital was not found as a significant mediator between news media and civic attitude $(\beta=0.028, t=1.36, p=.173)$. However, social capital significantly mediates between news media use and civic behavior $(\beta=0.147, t=5.13$, $p<.001)$. H6 receives partial support. In H7, civic accountability was predicted to mediate in the relationship between news media and civic attitude which was supported $(\beta=0.224, t=5.20, p<.001)$. Similarly, the relationship between news media and 
civic behavior was mediated by civic accountability $(\beta=0.10, \mathrm{t}=3.58, p<.001) . \mathrm{H} 7$ was supported.

\section{DISCUSSION}

This study examined the influence of news media on the civic engagement of youth in Pakistan. It is natural for individuals to have a keen interest in social events as humans are social animals who seek to bring a positive change resulting in an improved society. Individuals seek to keep abreast of the latest events and contribute to enhanced civic activities. Previous studies have measured civic engagement through civic actions (Campbell \& Kwak, 2010; Gil de Zuniga et al., 2012; Hao et al., 2014; Mushtaq \& Baig, 2015). The civic engagement scale used in this study assesses engagement through both civic attitude and behavior. Describing the rationale for measuring civic engagement as both attitude and behavior, Doolittle and Faul (2013) argue that an individual can't have a positive influence on one's community without having the appropriate competencies based on knowledge, skills, and values. An individual's expression of competency is based on both attitudes (likes and dislikes) as well as behaviors (actions toward specific desired goals).

This study suggests that news media has a positive relationship with civic behavior but not with civic attitude. The selection of news media appears to have a direct relationship with an individual's civic actions which have the potential to make a positive difference in one's community. However, news media do not appear to play a significant role as reflected in attitudes about civic affairs. These results are consistent with previous studies (Hoffman \& Thomson, 2009; Livingstone \& Markham, 2008; Mahmood \& Saud, 2019; Xenos \& Moy, 2007; Zubair \& Halim, 2017). These studies also prove that news media has positive effects on civic actions.

Consistent with the results of Uslaner (1998), we found that news media promotes social capital. Similarly, the findings revealed a significant relationship between news media use and civic accountability. It can thus be argued that news media use may be reflected in the sense of responsibility one assumes and further may encourage individuals to work for the betterment of society. Consistent with previous studies (Jalalani \& Shah, 2019; Son \& Lin, 2008), social capital has a direct relationship with civic behavior. Similar to H1a, this study found no relationship between social capital and civic attitude. While social capital is a significant mediator between news media and civic behavior. These results are further compatible with previous research by Collins, Neal, and Neal, 2014; Zhong, 2014. In addition, the results support the findings of Bonner (2009) that also suggests a positive association between civic accountability and civic attitude/behavior. This study also suggests that there is both a positive direct and indirect relationship between news media and civic accountability. The overall results are compatible with the tenets of the uses and gratification; younger 
individuals use news media to gratify needs which ultimately leads them towards engagement in civic activities. The results also support the tenets of the second-level agenda-setting that focuses on the attributes salience. Mass media sets the agenda for public discussion that can have a deep influence on civic engagement.

This study limits generalizability due to employing the convenience sampling technique. Its results can't be generalized to all younger individuals in Pakistan. Moreover, a cross-sectional survey design does not suggest causality. Despite these limitations, the current study contributes to the existing literature of media sociology by suggesting the presence of a mediating role of civic accountability between news media use and civic engagement. Moreover, these results can be helpful to social workers who intend to bring constructive change in society.

Future investigations should include people other than students in their sample to extend the generalization of the results. Additionally, future studies should use sampling methods which permit greater generalizability of the results. Future studies should also further investigate the proposed relationships within the framework of the $\mathrm{O}-\mathrm{S}-\mathrm{R}-\mathrm{O}-\mathrm{R}$ model. Research is also needed to explore the role of other mediating mechanisms such as interpersonal communication, civic knowledge, and civic efficacy. Future studies should separately measure the effects of different information mediums such as traditional media, new media, and interpersonal communication as predictors.

\section{RECOMMENDATIONS}

This study suggests that news media selection has an important influence on civic actions. Media use enhances civic engagement by enhancing social capital. This study also suggests relationship between news media on social capital and civic accountability. Civic accountability is also significantly correlated with civic attitude/behavior. Apart from direct effects, this study has also identified the indirect effects of social capital and civic accountability. Social capital mediates the relationship between news media use and civic behavior. Finally, this study supports civic accountability as a positive mediator which mediates between news media and civic attitude/behavior.

\section{ACKNOWLEDGEMENTS}

The authors would acknowledge Muhammad Ans, Assistant Registrar, Punjab Cooperative Department, for his advice, support, and constructive comments. 


\section{REFERENCES}

Baran, S. J., \& Davis, D. (2011). Mass Communication Theory: Foundations, Ferment, and Future. Delhi: Cengage Learning.

Bonner, M. D. (2009). Media as social accountability: The case of police violence in Argentina. The International Journal of Press/Politics, 14(3), 296-312. doi: $\underline{10.1177 / 1940161209334521}$

Bryant, J., \& Oliver, M. B. (2009). Media effects: Advances in theory and research (3rd ed.). Islamabad: National Book Foundation.

Campbell, S. W., \& Kwak, N. (2010). Mobile communication and civic life: Linking patterns of use to civic and political engagement. Journal of Communication, 60(3), 536-555. doi: 10.1111/j.1460-2466.2010.01496.x

Cheng, Y., Liang, J., \& Leung, L. (2015). Social network service use on mobile devices: An examination of gratifications, civic attitudes and civic engagement in China. New Media \& Society, 17(7), 1096-1116. doi: 10.1177/1461444814521362

Chin, W. W. (1998). The partial least squares approach to structural equation modeling. Modern Methods for Business Research, (pp. 295-336). New York: Psychology Press.

Cho, J., Rojas, H., \& Shah, D. V. (2003). Social capital and media. In K. Christensen \& D. Levinson, Encyclopedia of community: From the village to the virtual world (pp. 12911295). Thousand Oaks, CA: Sage.

Collins, C. R., Neal, J. W., \& Neal, Z. P. (2014). Transforming individual civic engagement into community collective efficacy: The role of bonding social capital. American Journal of Community Psychology, 54(3-4), 328-336. doi: 10.1007/s10464-014-9675-x

Doolittle, A., \& Faul, A. C. (2013). Civic engagement scale: A validation study. Sage Open, 3(3). doi: 10.1177/2158244013495542

Finkel, S. E., Sabatini, C. A., \& Bevis, G. G. (2000). Civic education, civil society, and political mistrust in a developing democracy: the case of the Dominican Republic. World Development, 28(11), 1851-1874. doi: 10.1016/S0305-750X(00)00067-X

Flanagan, C. A., Syvertsen, A. K., \& Stout, M. D. (2007). Civic Measurement Models: Tapping Adolescents' Civic Engagement. CIRCLE Working Paper 55. Center for Information and Research on Civic Learning and Engagement (CIRCLE).

Fornell, C., \& Larcker, D. F. (1981). Evaluating structural equation models with unobservable variables and measurement error. Journal of Marketing Research, 18(1), 39-50. doi: $10.2307 / 3151312$

Gil de Zuniga, H., Jung, N., \& Valenzuela, S. (2012). Social media use for news and individuals' social capital, civic engagement and political participation. Journal of ComputerMediated Communication, 17(3), 319-336. doi: 10.1111/j.1083-6101.2012.01574.x

Hair Jr, J. F., Hult, G. T. M., Ringle, C., \& Sarstedt, M. (2017). A primer on partial least squares structural equation modeling (PLS-SEM) (2nd ed.). Los Angeles: Sage publications.

Hair, J. F., Risher, J. J., Sarstedt, M., \& Ringle, C. M. (2019). When to use and how to report the results of PLS-SEM. European Business Review, 31(1), 2-24. doi: 10.1108/EBR-112018-0203 
Hao, X., Wen, N., \& George, C. (2014). News consumption and political and civic engagement among young people. Journal of Youth Studies, 17(9), 1221-1238. doi: 10.1080/13676261.2014.901490

Jalalani, R. A., \& Shah, N. (2019). Social Capital's Impact on Civic Engagement: An Empirical Study on Pakistani Youth. Grassroots, 53(1). Retrieved from https://tinyurl.com/yy6mk8ql

Katz, E., \& Blumler, J. G. (1974). The Uses of Mass Communications: Current Perspectives on Gratifications Research. California: Sage.

Kim, S. H. (2007). Media use, social capital, and civic participation in South Korea. Journalism \& Mass Communication Quarterly, 84(3), 477-494. $10.1177 / 107769900708400305$

Kiousis, S., \& McDevitt, M. (2008). Agenda setting in civic development: Effects of curricula and issue importance on youth voter turnout. Communication Research, 35(4), 481-502. doi: $10.1177 \% 2$ F0093650208315978

Leung, L. (2009). User-generated content on the internet: an examination of gratifications, civic engagement and psychological empowerment. New Media \& Society, 11(8), 1327-1347. doi: $10.1177 \% 2 \mathrm{~F} 1461444809341264$

Leung, L., \& Wei, R. (2000). More than just talk on the move: Uses and gratifications of the cellular phone. Journalism \& Mass Communication Quarterly, 77(2), 308-320. doi: $10.1177 \% 2 \mathrm{~F} 107769900007700206$

Liu, J., Qu, H., Huang, D., Chen, G., Yue, X., Zhao, X., \& Liang, Z. (2014). The role of social capital in encouraging residents' pro-environmental behaviors in community-based ecotourism. Tourism Management, 41, 190-201. doi: 10.1016/j.tourman.2013.08.016

Livingstone, S., \& Markham, T. (2008). The contribution of media consumption to civic participation 1. The British Journal of Sociology, 59(2), 351-371. doi: 10.1111/j.14684446.2008.00197.x

Mahmood, Q. K., \& Saud, M. (2019). Civic Participation and Facebook. In Proceedings of the 4th International Conference on Contemporary Social and Political Affairs (ICoCSPA 2018), 59-65. doi: 10.5220/0008816700590065

Martens, H., \& Hobbs, R. (2015). How media literacy supports civic engagement in a digital age. Atlantic Journal of Communication,23(2), 120-137. 10.1080/15456870.2014.961636

McCombs, M. E., \& Shaw, D. L. (1993). The evolution of agenda-setting research: Twentyfive years in the marketplace of ideas. Journal of Communication, 43(2), 58-67. doi: 10.1111/j.1460-2466.1993.tb01262.x

McLeod, J. M. (2000). Media and civic socialization of youth. Journal of Adolescent Health, 27(2), 45-51. doi: 10.1016/S1054-139X(00)00131-2

Molyneux, L. (2017). Multiplatform news consumption and its connections to civic engagement. Journalism, OO(0), 1-19. doi: 10.1177\%2F1464884917730216

Moon, S. J. (2013). Attention, attitude, and behavior: Second-level agenda-setting effects as a mediator of media use and political participation. Communication Research, 40(5), 698 719. doi: $10.1177 \% 2 F 0093650211423021$

Mushtaq, S., \& Baig, F. (2015). The Relationship of TV News Channels Consumption with Political Participation, Political Knowledge and Civic Engagement. Asian Social Science, 11(12), 46. doi: 10.5539/ass.v11n12p46 
Papacharissi, Z., \& Rubin, A. M. (2000). Predictors of Internet use. Journal of Broadcasting \& Electronic Media, 44(2), 175-196. doi: 10.1207/s15506878jobem4402_2

Putnam, R. D. (1995). (1995a). Bowling alone: America's declining social capital. Journal of Democracy, 6(1), 65-78. doi: 10.1007/978-1-349-62965-7_12

Putnam, R. D. (1995). Tuning in, tuning out: The strange disappearance of social capital in America. PS: Political Science \& Politics, 28(4), 664-684. doi: $10.1017 / \mathrm{s} 1049096500058856$

Putnam, R. D. (2000). Bowling alone: The collapse and revival of American community. New York: Simon and Schuster.

Rafique, Z., Khoo, S. L., \& Idrees, M. W. (2016). Civic engagement among the youth: empirical evidence from Kashmir, Pakistan. Humanomics, 32(3), 376-388. doi: 10.1108/H-122015-0077

Shah, D. V., McLeod, J. M., \& Yoon, S. H. (2001). Communication, context, and community: An exploration of print, broadcast, and Internet influences. Communication Research, 28(4), 464-506. doi: 10.1177\%2F009365001028004005

Shah, V., Nojin Kwak, R. Lance Holbert, D. (2001). " Connecting" and" disconnecting" with civic life: Patterns of Internet use and the production of social capital. Political Communication, 18(2), 141-162. doi: 10.1080/105846001750322952

Son, J., \& Lin, N. (2008). Social capital and civic action: A network-based approach. Social Science Research, 37(1), 330-349. doi: 10.1016/j.ssresearch.2006.12.004

Uslaner, E. M. (1998). Social capital, television, and the "mean world": Trust, optimism, and civic participation. Political Psychology, 19(3), 441-467. doi: 10.1111/0162$\underline{895 X .00113}$

Uslaner, E. M. (2018). The Oxford handbook of social and political trust. New York: Oxford University Press.

Warren, A. M., Sulaimsan, A., \& Jaafar, N. I. (2014). Social media effects on fostering online civic engagement and building citizen trust and trust in institutions. Government Information Quarterly, 31(2), 291-301. doi: 10.1016/j.giq.2013.11.007

Zhang, W., \& Chia, S. C. (2006). The effects of mass media use and social capital on civic and political participation. Communication Studies, 57(3), 277-297. doi: 10.1080/10510970600666974

Zubair, S., \& Halim, S. A. (2017). Uses of Social Networking Sites towards Civic Engagement in Pakistan and Egypt. International Journal of Research and Development in Social Sciences (IJRDS) 3(1), 40-56. Retrieved from https://tinyurl.com/yye32bfq 